\title{
Arbeidsmiljøet gir fremdeles sykdom
}

Skader og sykdom som følge av forhold på arbeidsplassen må unngås. Hvem er ansvarlig for gjennomføring av forebyggende tiltak? I første rekke er det bedriften. Bedriftshelsetjeneste og vernetjeneste har viktige oppgaver, men det har også bedriftsledelsen. Ledelsen kan sørge for et godt arbeidsmiljø i samarbeid med arbeidstakerorganisasjonene gjennom gode HMS-tiltak. Tilsynsmyndighetene har en sentral rolledels ved utforming av et hensiktsmessig regelverk, dels for å påse at dette overholdes. Når skaden først er skjedd, bør fastleger og sykehus mistenke og diagnostisere arbeidsrelatert sykdom. Mye av den endelige diagnostikken tas hånd om av de arbeidsmedisinske avdelinger, men også av andre relevante spesialavdelinger, spesielt lungeavdelinger og hudavdelinger. De arbeidsmedisinske avdelinger har dessuten ekspertkompetanse for å kartlegge kompleks eksponering.

Tidsskriftet publiserer nå flere artikler der dagens arbeidsmedisinske utfordringer belyses. Spekteret av eksponering varierer over tid, blant annet knyttet til næringsutviklingen i samfunnet. Historisk har primærforebyggende tiltak utvilsomt hatt betydning, men det er fremdeles utfordringer - for eksempel kommer det stadig nye kjemiske produkter på markedet. I andre tilfeller er det velkjente eksponeringer som gir opphav til nye sykdomstilfeller. Det kan enten skyldes at sykdommen har lang latenstid (f.eks. yrkesbetinget kreft) eller det har vært mangelfull overvåking av løpende eksponering.

Et eksempel på det siste er arbeidsrelatert hørselstap, som er beskrevet av Samant og medarbeidere i dette nummer av Tidsskriftet (1). Leger har ifølge arbeidsmiljøloven plikt til å sende melding til Arbeidstilsynet ved mistanke om arbeidsrelatert sykdom. Hørselstap er den vanligste tilstand som meldes. Forfatterne har gjennomgått meldinger om hørselstap i tidsrommet 2002-09 og påpeker svakheter ved meldesystemet. Et uløst problem er at mange arbeidsgivere mangler systematiske retningslinjer som sikrer arbeidstakerne mot uforsvarlig støybelastning og prosedyrer for å fange opp støyskade i en tidlig fase. Virksomheter (spesielt små) som mangler bedriftshelsetjeneste, kan være svake på dette området.

Lungekreft innebærer omfattende utfordringer i klinisk diagnostikk og behandling, men også vurdering av årsaksaksforhold krever betydelig oppmerksomhet. I de fleste tilfeller er det lang latenstid - og i ettertid kan det være vanskelig å få sikre opplysninger om eksponering. Tidligere studier, også fra Norge, taler for at omkring $20 \%$ av tilfellene kan ha bakgrunn i eksponering i arbeid $(2,3)$. I dette nummer av Tidsskriftet rapporteres det fra St. Olavs hospital, der man over en periode på 2,5 år fortløpende undersøkte nydiagnostiserte pasienter innlagt for lungekreft (4). For menn konkluderte man med at ca. $38 \%$ av krefttilfellene (28 av 73) var sannsynlig eller mulig yrkesbetinget. For kvinnene var det ingen sammenheng. Selv om årsaksvurdering prinsipielt kan være problematisk i enkelttilfeller (5), er artikkelen en nyttig påminnelse om at yrkeseksponering kan være årsak. Henvisning til arbeidsmedisinsk avdeling bør derfor overveies ved mange typer kreft, og spesielt gjelder det lungekreft.

Kronisk obstruktiv lungesykdom (kols) er utbredt i befolkningen (6). Tidligere var røyking regnet som den helt dominerende årsaksfaktor. Dette bildet er nå i ferd med å endres. I Fell og medarbeideres artikkel refereres funn fra en rekke undersøkelser der det dokumenteres at eksponering $\mathrm{i}$ arbeid og at miljøet for øvrig kan være årsak til kols (7). Dette er viktig kunnskap for å kunne forebygge sykdommen, og gir også et grunnlag for korrekt erstatning til pasienten. Også her kan bedømmelse av årsaksforholdet være kontroversielt, da mange av disse pasientene også røyker.
For arbeidsrelatert astma gir tidlig diagnose og intervensjon på arbeidsplassen bedret prognose (8). Spesielt når det er en allergisk mekanisme, kan det være mulig å stille en nøyaktig etiologisk diagnose (9). I andre tilfeller kan irriterende gasser og støv (irritanter) forverre tilstanden hos pasienter med allerede etablert astma. Dette er spesielt viktig når unge mennesker med astma skal velge yrke. I mange tilfeller med nyoppstått arbeidsrelatert astma er rådet fra legen å unngå eksponering. Fordi dagens system ikke gir tilstrekkelig trygghet, kan mange av disse pasientene havne i et økonomisk uføre (10).

Artiklene illustrerer mange av dagens utfordringer på arbeidsmiljøfeltet. Det er behov for betydelig innsikt i diagnostikk, men også forståelse av arbeidsmiljøeksponering. Slik kan vi bedre vurdere årsaksforhold ved arbeidsrelatert sykdom. En slik forståelse danner grunnlaget for effektiv forebyggende innsats og kan sikre at pasientene får den erstatning de har krav på.

Tor Olav Brøvig Aasen

tor.olav.brovig.aasen@helse-bergen.no

Johny Kongerud

Tor Olav Brøvig Aasen (f. 1946) er spesialist i lungesykdommer og i indremedisin, med spesiell kompetanse innen arbeidsrelaterte lungesykdommer. Han er tidligere avdelingsoverlege og avdelingsdirektør ved Yrkesmedisinsk avdeling, Haukeland universitetssykehus, nå spesialrådgiver/ pensjonist.

Forfatter har fylt ut ICMJE-skjemaet og oppgir ingen interessekonflikter.

Johny Kongerud (f. 1949) er avdelingsleder ved Lungeavdelingen, Oslo universitetssykehus, Rikshospitalet, og professor II ved Universitetet i Oslo. Han er spesialist i indremedisin og i lungesykdommer og har mangeårig forskningserfaring og klinisk erfaring innen feltet yrkesbetingede lungesykdommer.

Forfatter har fylt ut ICMJE-skjemaet og oppgir ingen interessekonflikter.

Litteratur

1. Samant $Y$, Lysberg $L$, Landrø $M$ et al. Legers melding om arbeidsrelatert hørselstap. Tidsskr Nor Legeforen 2014: 134: 1950-4.

2. Kjuus $\mathrm{H}$, Skjaerven $\mathrm{R}$, Langård $\mathrm{S}$ et al. A case-referent study of lung cancer occupational exposures and smoking. II. Role of asbestos exposure. Scand J Work Environ Health 1986; 12: $203-9$.

3. Kjuus H, Skjaerven R, Langård S et al. A case-referent study of lung cancer occupational exposures and smoking. I. Comparison of title-based and exposure-based occupational information. Scand J Work Environ Health 1986 12: $193-202$

4. Slåstad S, Leira HL, Aas 0 et al. Arbeidsbetinget lungekreft i Sør-Trøndelag. Tidsskr Nor Legeforen 2014; 134: 1943-7.

5. Strandberg M, Aasen TB. Yrkeskadetrygdens hovedårsakskrav og fordelingslære. Tidsskrift for erstatningsrett 2013; 10: 148-72.

6. Helsedirektoratet. Nasjonal faglig retningslinje og veileder for forebygging, diagnostisering og oppfølging av personer med kols. http://helsedirektoratet.no/ publikasjoner/nasjonal-faglig-retningslinje-og-veileder-for-forebyggingdiagnostisering-og-oppfolging-av-personer-med-kols/Documents/ IS-2029Revidert.pdf. (16.10.2014).

7. Fell AK, Aasen TB, Kongerud J. Arbeidsrelatert kols. Tidsskr Nor Legeforen 2014; 134. Akseptert for publisering.

8. Aasen TB, Kongerud J. Arbeidsrelatert astma - diagnostikk og oppfølging Tidsskr Nor Legeforen 2014; 134: 1955-9.

9. Pepys J, Hutchcroft BJ. Bronchial provocation tests in etiologic diagnosis and analysis of asthma. Am Rev Respir Dis 1975; 112: 829-59

10. Wergeland E. I strid med arbeidervernloven. Dagens Medisin 2011 www.dagensmedisin.no/debatt/i-strid-med-arbeidervernloven/ (15.10.2014). 